\title{
MASYARAKAT MADANI DALAM KASUS POLITIK ISLAM MENURUT NURCHOLISH MADJID (1939-2005)
}

Mata Kuliah Kewarganegaraan

Dosen Pengampu: Dr. Agustinus Wisnu Dewantara, S.S.M.Hum

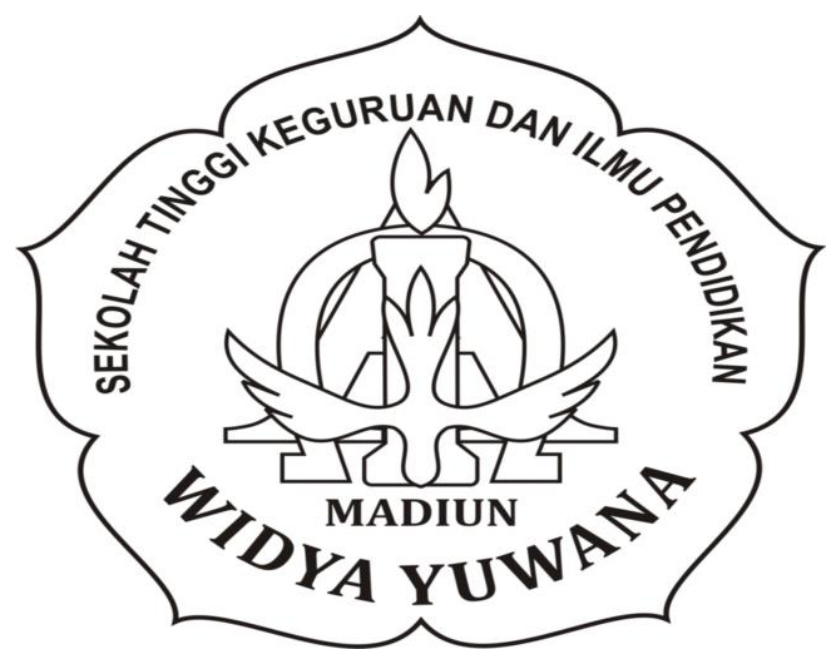

Disusun oleh:

Marsela Trihastuti Hendra

152846

SEKOLAH TINGGI KEGURUAN DAN ILMU PENDIDIKAN WIDYA

YUWANA

MADIUN

2019 


\section{Latar Belakang}

Salah satu problem serius yang muncul dalam wacana politik Islam adalah kaitan antara agama dan politik. Kaum muslim tradisional berpendapat, Islam tidak memisahkan antara agama dan politik, Islam adalah sistem agama sekaligus sistem negara, karena itu pula Islam sebagai agama meniscayakan suatu wahana pemersatu yaitu negara. Pandangan yang menegaskan bahwa Islam sebagai agama pribadi yang terpisah dari politik (sekuler), secara diametral ditolak oleh kaum muslim tradisionalis. Salah satu contoh yang relevan dari wacana dan gerakan politik kaum muslim tradisionalis adalah pendirian negara Pakistan, yang ditujukan untuk menjaga kepentingan kaum Muslim dari mayoritas Hindu di India. Dalam pandangan Abul A'la alMaududi, seperti di kutip Kennet Cragg, alasan awal yang mendorong pendiri negara Pakistan oleh kaum tradisionalis sangatlah sekuler, yaitu untuk menjaga kepentingan material kaum muslim, karena itu, al-Maududi awalnya amat menentang pendiri Pakistan.(Cragg, 1965:21-23).

Negara dalam pandangan kaum tradisionalis muslim dibutuhkan sebagai sarana aktualisas dan pelaksanaan ketentuan syari'at Islam yang di rumuskan oleh ulama. Dalam penilaian Mohammed Arkoun wacana politik Islam tradisionalis tidak mampu memuaskan pengetahuan bersama tentang kaitan agama dengan politik dalam Islam. Belum pula dapat menjadi refleksi warisan pemikiran serta praktik Islam yang terbentuk sejak abad ke-2 H, yang notabenenya merupakan rujukan historis segenap konsepsi pengetahuan praktis Islam, termasuk bidang politik. Menurut Arkoun praktik historis perpolitikan yang diperlihatkan Nabi tidak memperlihatkan adanya keharusan untuk membentuk negara Islam, dalam arti Islam tidak menuntut pembentukan negara Islam. Arkoun dalam hal ini menolak pembentukan negara Islam dan lebih menyetujui pembentukan negara demokrasi tanpa mempertentangan antara nalar agama dan nalar filsafat.

Dalam hal ini Arkoun menginginkan sebuah negara demokratis, namun bukan dalam bentuk negara yang secara tegas menggantikan angan-angan agama dengan angan-angan negara sekuler-republik, seperti yang terjadi pada negara Barat-sekuler. Negara demokratis tetap perlu menyelaraskan antara wewenang keagamaan dengan kekuasaan politik yang dijalankan secara demokratis, karena disadari atau tidak tiap warga negara tetap memiliki dua dimensi kedekatan, yaitu kedekatan spiritual dan kedekatan sekuler. Kedekatan spiritual ini muncul dalam kesamaan aqidah sedangkan kedekatan sekuler ini muncul dalam bentuk kesamaan bahasa, budaya, dan 
wilayah. Karena itu, yang dibutuhkan umat Islam dewasa ini bukan semata sistem negara yang diikat oleh kedekatan spiritual (negara teokrasi), akan tetapi juga sistem negara yang dibangun berdasarkan kedekatan sekuler (negara-bangsa).

Berdasarkan penjelasan diatas, Arkoun sebenarnya ingin menyatakan bahwa konsep negara dalam Islam idealnya adalah negara sekuler. Namun istilah "sekuler" yang dipakai Arkoun sebelumnya telah dimaknai secara baru dan terlepas dari pemaknaan sekuler yang berkembang di dunia Barat. Menurut Arkoun, sekulerisme merupakan satupemikiran atau gerakan penting dalam membebaskan nalar manusia dari segala bentuk kesadaran yang keliru (mitologi). Sekulerisme lebih dari sekedar pemisahan sederhana antara hal-hal yang spiritual dan yang temporal (duniawi), karena kenyataannya sekulerisme amat kental dalam tradisi Islam seperti terlihat dalam pengalaman negara Madinah ketika Nabi melakukan pembelaan terhadap kaum yang tertindas.

Penjelasan Arkoun di atas, hanya satu sisi dari dua mata koin yang ingin diangkat ke permukaan, karena pada sisi lain terdapat pandagan kalangan muslim tradisional yang menolak terbentuknya negara sekuler. Artinya, umat Islam dewasa ini sebenarnya menghadapi satu isu politik yang cukup pelik dan belum sepenuhnya terpecahkan, yaitu tentang bentuk negara dalam kaitannya dengan pemahaman terhadap hubungan antara agama dan negara.

Pada satu sisi, kalangan muslim tradisionalis melihat bahwa Islam tidak terpisah dari negara dan Islam sendiri merupakan agama sekaligus negara, karena itu dibutuhkan negara Islam sebgai wahana untuk memelihara kepentingan umat Islam.

\begin{tabular}{|c|}
\hline KASUS : \\
Permasalahan yang terus melanda ilmu-ilmu sosial hingga saat ini adalah \\
ketidakmampuan menjelaskan apa dan bagaimana seharusnya tatanan ideal sebuah \\
masyarakat. Civil Society, yang selama ini menjadi sebuah paradigma ideal mengenai \\
masyarakat dalam diskursus para ahli di Barat, terus mengalami kebingungan dan distorsi \\
konseptual ketika pemahaman itu harus diaplikasikan dalam aktifitas masyarakat riil. \\
Walhasil, teori-teori yang dihasilkan oleh ilmu-ilmu sosial pasca renaisans ini terbatas pada \\
wacana yang tidak pernah membumi. Namun, jauh empat belas abad yang lalu, telah \\
berdiri sebuah masyarakat yang mampu melakukan lompatan besar peradaban dengan \\
berdirinya sebuah komunitas yang bernama Masyarakat Madinah (Umari, 1999: 69). \\
Transformasi radikal dalam kehidupan individual dan sosial mampu merombak
\end{tabular}


secara total nilai, simbol, dan struktur masyarakat yang telah berakar kuat dengan

membentuk sebuah tatanan baru yang berlandaskan pada persamaan dan persaudaraan. Bentuk masyarakat Madinah inilah, yang kemudian ditransliterasikan menjadi "Masyarakat Madani”, merupakan tipikal ideal mengenai kosepsi sebuah masyarakat Islam. Eksistensi masyarakat Madinah tidaklah serta merta terbentuk begitu saja, melainkan melalui sebuah proses panjang. Namun, lompatan besar yang berhasil dilakukan oleh masyarakat Madinah pada masa itu adalah sebuah proses panjang dari kemampuan mereka mengaplikasikan nilai dan simbol Islam secara bersamaan. Nilai Islam ini bersumber dari al-Qur'an dan perintah Nabi sebagai penjelasan nilai-nilai tersebut. Nilai-nilai Islam sebagai dasar terbentuknya masyarakat merupakan buah sosialisasi nilai yang dilakukan Nabi dan sahabat selama tiga belas tahun di Makkah.

Dengan demikian, saat proklamasi masyarakat Madinah, setiap individu tidak lagi mengalami kebingungan dengan apa dan bagaimana seharusnya mereka bertindak. Simbol Islam menjadi penting dalam proses pembangunan masyarakat Madinah yang membedakan sebuah masyarakat baru ini dengan masyarakat jahiliyah yang ada di sekitarnya. Simbol Islam merupakan bentuk aktualisasi nilai-nilai Islam ke dalam konteks lingkungan sosial pada masa tersebut. Karenanya, keberadaan simbol-simbol Islam menjadi lekat dengan kewajiban individu muslim menjalankan syi'ar Islam. Sehingga, gaung Islam semakin menggema di dunia. Sementara itu, Piagam Madinah menjadi sebuah konsepsi fenomenal dan sangat penting yang mampu mengabadikan masyarakat di Madinah sebagai sebuah masyarakat ideal yang melegenda sepanjang masa. Pada masa itu, nilai, simbol, dan struktur sosial masyarakat merupakan sebuah warisan dari para leluhur yang tidak boleh diganggu-gugat. Namun, Nabi dan masyarakat Madinah melakukan sebuah terobosan sejarah dengan membuat sebuah kontrak sosial di dalam masyarakat yang baru terbentuk tersebut. Dari Piagam Madinah inilah kemudian banyak pemikir di era Revolusi Perancis yang menandakan perubahan di masyarakat Eropa.

Rousseau dalam Social Contract-nya juga tidak lepas dari pengaruh Islam. Bahkan dia secara jelas menyebut: "Muhammad memiliki kekuatan besar yang mampu menjaga persatuan dalam sistem politik masyarakatnya, dan selama pemerintahannya mampu melahirkan kekhalifahan yang dapat mewarisi kesuksesannya, pemerintah menjadi bagian yang tidak terpisahkan dari masyarakat, hal inilah yang membuat masyarakat muslim 
semakin berkembang.” (Azizi, 2000: 94). Piagam Madinah merupakan sebuah kontrak sosial yang pertama di dunia ketika setiap elemen masyarakat memiliki kesempatan untuk berpartisipasi dalam proses pembentukannya sebagai elemen penting dalam politik masyarakat. Kotrak sosial merupakan sebuah prasyarat mutlak dalam rangka pembentukan Masyarakat Madani. Keberadaannya merupakan sebuah proses inovatif yang memadukan antara nilai dasar Islam dengan kondisi situasional di setiap zaman. Mengambil istilah Marx, bahwa setiap periode memiliki mode of production yang berbeda-beda (Allan, 1951: 76). Hal serupa pun menjadi sebuah karakteristik umum pembentukan kontrak sosial dalam masyarakat Madani selanjutnya, yang mampu menyesuaikan dengan kondisi di mana nilai Islam dari teks suci al-Qur'an dan sunnah diinterpreatasikan berdasarkan konteks kehidupan masyarakat pada masanya.

\section{Penjelasan dari kasus diatas}

Permasalahan yang terjadi saat ini adalah ketidakmampuan kaum muslimin menjalankan nilai dan simbol Islam secara bersamaan yang saling berkaitan erat. Individu dan masyarakat muslim seakan tertarik pada dua kutub ekstrim antara nilai atau simbol keagamaan yang terbawa oleh peradaban di luar Islam. Pada satu sisi, nilai keagamaan, mendominasi masyarakat dengan cengraman yang sangat kuat. Akibatnya, setiap individu muslim dalam masyarakat mengkultuskan nilai-nilai Islam sebagai sesuatu yang sangat sakral. Kondisi tersebut menjadikan masyarakat jauh dari realitas sosialnya yang berdampak pada terkucilnya Islam pada sudut-sudut masjid atau "goa-goa yang jauh dari peradaban". Mereka tidak mampu menciptakan sebuah produk nilai Islam yang terintegrasi dengan konteks sosial masyarakat.

\section{Masyarakat Madani Indonesia}

Masyarakat madani jika dipahami secara sepintas merupakan format kehidupan alternatif yang mengedepankan semangat demokrasi dan menjunjung tinggi nilai- nilai hak asasi manusia. Hal ini diberlakukan ketika negara sebagai penguasa dan pemerintah tidak bisa menegakkan demokrasi dan hak asasi manusia dalam menjalankan roda pemerintahannya. Disinilah kemudian, konsep masyarakat madani menjadi alternatif pemecahan, dengan pemberdayaan dan pengembangan daya kontak masyarakat terhadap kebijakan-kebijakan pemerintah yang pada dasarnya nanti terwujud kekuatan masyrakat sipil yang mampu merealisasikan dan menegakkan konsep hidup yang demokratis dan menghargai hak-hak asasi manusia. 
Sosok masyarakat madani bagaikan barang antik yang memiliki daya tarik amat mempesona. Kehadirannya yang mampu menyemarakkan wacana politik kontemporer dan meniupkan arah baru pemikiran politik, bukan dikarenakan kondisi barangnya yang sama sekali baru, melainkan disebabkan tersedianya momentum kondusif bagi pengembangan masyarakat yang lebih baik.

Berbicara mengenai kemungkinan berlembaganya masyarakat madani di Indonesia diawali dengan peristiwa pelanggaran HAM dan pengencangan kebebasan berpendapat, berserikat dan kebebasan untuk mengemukakan pendapat dimuka umum kemudian dilanjutkan dengan munculnya berbagai lembaga- lembaga non pemerintah yang mempunyai kekuatan dan bagian dari social control. Sejak zaman orde lama dengan rezim demokrasi terpimpinnya Soekarno, sudah terjadi manipulasi peran serta masyarakat untuk kepentingan politisi dan terhegemoni sebagai alat legitimasi politik. Hal ini pada akhirnya melibatkan kegiatan dan usaha yang dilakukan oleh anggota masyarakat diwarnai sebagai kontra- revolusi. Fenomena tersebut merupakan salah satu indikasi bahwa di Indonesia pada masa Soekarno pun mengalami kecendrungan untuk membatasi gerak dan kebebasan publik dalam mengeluarkan pendapat.

Agama di Indonesia mengambil peranan penting dalam pembentukan masyarakat sipil. Khususnya sebagai masyarakat politik. Perkembangan masyarakat sipil ini ternyata lebih cepat dari pada perkembangan masyarakat ekonomi. Sebagai dampaknya, peranan negara lain menonjol dan justru mengambil peran sebagai agen perubahan sosial yang berdampak terbentunya masyarakat sipil, dari arti mencakup masyarakat politik maupun ekonomi.

Kecendrungan yang dominan di Indonesia adalah idealisasi negara, sebagai wadah nilainilai tertinggi. Perjuangan organisasi- organisasi keagamaan ikut mendorong terbentunya negara ideal, atau negara integralistik sebagai kompromi dari konflik antara sekularisme dan teokrasi. Karena itu nilai-nilai keagamaan perlu dikembangkan dengan memperkuat masyarakat sipil, sebagai benteng (bastion) kepentingan-kepentingan dan aspirasi masyarakat dimana agama kedudukannya cukup dominan dalam masyarakat Indonesia

Peranan agama yang kuat di Indonesia, sangat mendukung terwujudnya masyarakat Indonesia baru yang populer diistilahkan Nurcholish Madjid sebagai masyarakat madani. Disini, negara dipandang sebagai wadah dan sekaligus perwujudan nilai-nilai luhur yang bersumber pada agama. Itulah yang menjelaskan mengapa di Indonesia, demokrasi di beri predikat 
pancasila. Karena demokrasi yang dikehendaki berlaku di Indonesia adalah demokrasi untuk merealisasikan nilai-nilai luhur tujuannya seluruh agama.

http://journal.unair.ac.id/MKP@wacana-masyarakat-madani-(civil-society)-relevansi-untukkasus-indonesia-article-2580-media-15-category-8.html https://www.kompasiana.com/imambasori.com/555471c8b67e611318ba543d/revitalisasimasyarakat-madani

\section{Gerakan Politik Islam Tradisional dan Liberal}

Yang perlu di ketahui dan perlu dicatat di sini, yaitu dimana gerakan fundamentalisme Islam, tidak dapat secara gamblang disamakan dengan tradisionalisme Islam, karena tradisionalisme sendiri juga memiliki keragaman. Nahdhatul Ulama misalnya, dalam kenyataannya juga merupakan organisasi kalangan islam tradisional yang didirikan untuk merespon organisasi kalangan Islam liberal. Hanya saja NU tidak begitu konsern dengan masalah politik, dan cenderung membatasi diri pada masalah keagamaan, walaupun selanjutnya pernah terlibat dalam perpolitikan Islam namun ia kembali kepada hittahnya. Artinya perbedaan terhadap suatu gerakan sebenarnya harus dilihat perkasus, atau bahkan pertokoh dan jug aide-ide. Hal ini penting dikemukakan untuk memahami penjelasan berikut tentang wacana dan gerakan Islam liberal dalam menyokong negara sekuler.

Berseberangan dengan kalangan Islam tradisionalis, kalangan Islam liberalis di Indonesia secara tegas menolak penyatuan agama dan negara dalam bentuk pendirian negara Islam dan penerapan syari'at Islam sebagai landasan ideology sebuah negara. Dalam praktik kenegaraan di Indonesia, jika Indonesia dapat dikatakan negara sekuler-republik di Indonesia cenderung gagal dalam arti gagal dalam membangun prasarana sosial budaya untuk menopang sebuah konsep kenegaraan modern.

Pemerintahan di era Reformasi terlihat juga banyak mengaami kegagalan dalam membina nation-state dalam berbagai kasus yang memperlihatkan berbagai tuntutan daerah untuk melepaskan dri dari teritori kedaulatan Indonesia. Walaupun klaim kegagalan tidak bijak diberikan secara terburu-buru. (Disari al-Chaidar, 1998:137-160)

Fakta-fakta yang ada tersebut memperlihatkan bahwa konsep dan praktik negara Islam dan negara sekuler yang pernah eksis di Indonesia memiliki sisi lemahnya msing-masing. 


\section{Masyarakat Madani: Alternatif Pengurai Masalah}

Merujuk pada pemahaman Islam yang insklusif, terdapat satu wacana yang penitng dibicarakan seputar hubungan antara Islam dan negara, untuk menjamin terbentuknya negara yang baik, yaitu konsep masyarakat madani. Konsep masyarakat madani menurut Bahtiar Effendy identik dengan istilah civil society yang dikenal dewasa ini. Kata masyarakat madani jelas mempunyai arti dan makna dengan istilah aslanya, yaitu masyarakat berperadaban, bukan masyarakat sipil sebagaimana yang bisa disalahpahami secara leterjik atau verbatim. Masayarakat madani ini bukanlah lawan dari militer yang muncul dari anggapan perlawanan antara sipil dan militer, masyarakat madani ini justru terkait terkait dengan persoalan kehidupan berbangsa dan bernegara dalam arti bangunan dari prilakupolitik yang erat kaitannya dengan nilai-nilai demokrasi.

Prinsip di atas menunjukkan bahwa negara dalam Islam seperti perbedaan bahasa, warna kulit, atau keturunan, namun lebih merupakan negara yang didasarkan oleh solidaritas iman dan hukum. Di dalamnya tiap individu masyarakat memperoleh kebebasan dalam beragama namun terkait oleh hukum yang satu.

\section{Pandangan Terhadap Masyarakat Madani Menurut Nurcholish Majdid}

Salah satu tokoh Indonesia yang mengumandangkan konsep masyarakat madani adalah Nurcholish Majdid. Ia mengacu pada konsep "negara kota Madinah" yang dibangun Nabi Muhammad SAW pada 622 M, yaitu "masyarakat yang berperadaban" "ber-madinah" karena tunduk dan patuh kepada ajaran kepatuhan yang dinyatakan dalam supermasi hukum dan peraturan. Oleh karenanya, masyarakat madani merupakan reformasi total terhadap masyarakat tak kenal hukum "lawless" Arab Jahiliyah yang dapat melahirkan masyarakat yang berperadaban, sehingga "masyarakat madani juga mengacu pada konsep tammadun (masyarakat berperadaban).

Dengan demikian, dapat dikatakan bahwa masyarakat madani adalah salah satu komunitas masyarakat "terbaik" yang memiliki "kemandirian" dalam aktivitas warga masyarakatnya dan berkembang sesuai dengan potensinya. Ini diwujudkan dengan memberlakukan nilai-nilai keadilan, pengakuan hukum, jaminan kesejahteraan, kebebasan, kemajemukan (pluralisme), dan perlindungan terhadap kaum minoritas. Jadi, masyarakat madani adalah "masyarakat mandiri dan bertanggung jawab, masyarakat yang berkembang dari rakyat untuk rakyat itu sendiri”, masyarakat yang sadar akan hak dan kewajibannya dan hidup dalam 
demokrasi dengan berbagai perbedaan kelompok etnis, ras, suku bangsa, budaya, agama dan lain-lain sebagai wujud masyarakat multikulturaisme.

\section{Kesimpulan}

Dari semua permasalahan yang ada di atas, dapat disimpulkan bahwa Islam sebagai way of life (syari'ah) pada dasarnya tidak secara spesifik menyatakan keberpihakan pada satu system kenegaraan apakah teokrasi ataupun sekuler. Karena itu dapat dikatakan bahwa sistem negara tidak ada dalam Islam. Hanya saja jika kita merujuk pada sejarah Islam, maka system kenegaraan yang ditunjukkan nabi dalam kehidupan masyarakat madani yang beradab, toleran, demokratis, dan menjunjung hak-hak kemanusiaan, ini merupakan contoh terbaik dalam membangun system kenegaraan yang berporos pada ajaran Islam. Yaitu sebuah negara demokratis, namun bukan dalam bentuk negara yang secara tegas menggantikan angan-angan agama dengan angan-angan negara sekuler-republik, seperti yang terjadi pada negara-negara Barat-sekuler. 


\section{DAFTAR PUSTAKA}

Dewantara, Agustinus Wisnu. "MULTIKULTURALISME INDONESIA (STUDI PERBANDINGAN ANTARA KONSEP MADANI NURCHOLISH MADJID DAN KONSEP CIVIL SOCIETY)." JPAK: Jurnal Pendidikan Agama Katolik 17.9 (2017): 15-25.

Dewantara, Agustinus Wisnu. "NURCHOLISH MADJID DAN KONSEP CIVIL SOCIETY."

http://journal.unair.ac.id/MKP@wacana-masyarakat-madani-(civil-society)-relevansi-untuk-kasusindonesia-article-2580-media-15-category-8.html

https://www.kompasiana.com/imambasori.com/555471c8b67e611318ba543d/revitalisasi-masyarakat$\underline{\text { madani }}$

Kewuel. 2011. mengolah pluralitas agama, Malang: penerbit serva minora (anggota ikap). Zuhairini, Sejarah Pendidikan Islam, Jakarta: Bumi Aksara dan DEPAG, 1977 Cet. Ke-5. 